\title{
Reviewer Acknowledgements for Global Journal of Health Science, Vol. 12, No. 9
}

Global Journal of Health Science wishes to acknowledge the following individuals for their assistance with peer review of manuscripts for this issue. Their help and contributions in maintaining the quality of the journal are greatly appreciated.

Global Journal of Health Science is recruiting reviewers for the journal. If you are interested in becoming a reviewer, we welcome you to join us. Please contact us for the application form at: gjhs@ccsenet.org.

\section{Reviewers for Volume 12, Number 9}

Abiodun Adeniran, University of Ilorin, Nigeria

Ama Pokuaa Fenny, University of Ghana, Ghana

Angel Alfonso Velarde Lopez, University of Pennsylvania, Guatemala

Ayesha Johnson, University of South Florida, United States of America

Farahnaz Amini, UCSI University, Malaysia

Gabriel Gulis, University of Southern Denmark, Denmark

Gabriele Messina, University of Siena, Italy

Horng-Jyh Tsai, Kuang Tien General Hospital, Taiwan

Kartheek R Balapala, University Tunku Abdul Rahman, Malaysia

Marcel Wullschleger, University of Bern, Switzerland

Pi-Ming Yeh, Missouri Western State University, United States of America

Samir Othman, Hawler Medical University, Iraq

Steven Hoffman, Brigham Young University, United States of America

Soon Soo Hoo, Royal North Shore Hospital, Australia

Thammanard Charernboon, Thammasat University, Thailand

Thanusin Saleeon, Ministry of Public Health, Thailand 